\title{
Pengaruh Kualitas Pelayanan, Harga dan Suasana Café Terhadap Kepuasan Konsumen Pada Café About Something Palangka Raya
}

\author{
Jeni Makarueh ${ }^{1}$, Sri Rohaetin $^{2}$, Dehen Erang ${ }^{3}$

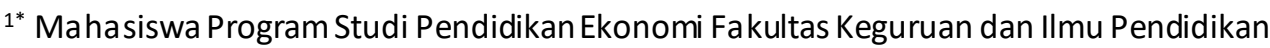 \\ Universitas Palangka Raya \\ 2,3Program Studi Pendidikan Ekonomi Fa kultas Keguruandan Ilmu Pendidikan Universitas Palangka Raya \\ *Corres pondence author: Jenimakarueh@gmail.com; Tel.: +62813576643XX
}

\begin{abstract}
This study aims to determine: 1) Does service quality affect consumer satisfaction, 2) Does price affect consumer satisfaction, 3) Does cafe atmosphere affect consumer satisfaction of all consumers at Cafe About Something Palangka Raya. The method used is descriptive and the determination of the sample does notusethe solvin formula because the population is infinity. Sources of data in this study were 96 respondents, whilethelist of questions was made based on 4 variables, namely: Service Quality, Price, Cafe Atmosphere, Consumer Satisfaction. Interview data collection techniques, observation, and documentation. The data analysistechnique used is the percentage of the frequency distribution. The results showed that consumer satisfaction About something coffee on the Service Quality variable was very satisfied, namely 38\%, satisfied 46\%, quite satisfied $13 \%, 2 \%$ less satisfied, $0.1 \%$ dissatisfied, the price variable was very satisfied, namely $27 \%$, satisfied $43 \%$, quite satisfied $25 \%$, less satisfied $5 \%$, atmosphere variable very satisfied that is 31\%, satisfied $51 \%$, quite satisfied $15 \%$, dissatisfied $3 \%$. And variable customer satisfaction very satisfied that is 33\%, satisfied $49 \%$, quite satisfied $16 \%$. The highest level of consumer satisfaction is in the atmosphere dimension 51\% in the "Satisfied" column in the statement The layout or layout in About Something is appropriate and neat and the lowest level of customer satisfaction is in the service quality dimension 3\% in the dissatisfied column on the statement that the building facilities in About Something Coffee are complete (toilet, fan, table/chair).
\end{abstract}

Keywords: Service Quality Price, Cafe Atmosphere, Consumer Satisfaction

\begin{abstract}
Abstrak: Penelitian ini bertujuan untuk mengetahui:1) Apakah kualitas pelayanan berpenga ruh terhadap kepuasan konsumen, 2) Apakah harga berpengaruh terhadap kepuasan konsumen, 3) Apakah sua sa na cafe berpenga ruh terhadap kepuasan konsumen dari semua Konsumen Pada Ca fe About SomethingPalangka Raya. Metode yang digunakan a da lah deskriptif dan penentua n sa mpel ti dak menggunakan rumus solvindikarenakan populasi yang bersifat infi nity. Sumber da ta dalam penelitian iniadalah96responden,adapundaftarpertanyaan yang dibuat berdasarkan 4 va riabel yaitu: Kual itas Pel ayanan, Ha rga,Suasana Cafe,KepuasanKonsumen. Teknik pengumpulan data wawancara, Observasi, dan Dokumentasi. Teknik analisis data yang digunakan ialah persentase distribusi frekuensi. Hasil penelitian menunjukan ba hwa kepuasan konsumen About something coffee pada variable Kualitas Pelayanan sangat puas yai tu $38 \%$, puas $46 \%$,cukuppuas $13 \%, 2 \%$ kurangpuas, $0,1 \%$ tidak puas, Variabel harga sangat puas yaitu $27 \%$, puas $43 \%$, cukup puas $25 \%$,kurangpuas $5 \%$,variablesuasana sangat puas yaitu $31 \%$, puas $51 \%$, cukup puas $15 \%$, kurang puas $3 \%$. Dan variable kepuasan pelanggansangat puas yaitu $33 \%$, puas $49 \%$, cukup puas $16 \%$. Tingkat kepua san kons umen yang paling tinggiada pada dimensi suasana $51 \%$ pada kolom "Puas" pada pernyataan Tata letak atau layout yang a da di AboutSomethingsudah sesuai dan rapi dan tingkat kepuasan konsumen yang paling rendah ada pada dimensi kualitas pelayanan $3 \%$ pada kolom tidak puas pada pernyataan fasilitas Gedung yang a da di About Something Coffeelengkap(toilet, kipas angina, meja/kursi).
\end{abstract}

Kata Kunci: Harga Kualitas Pelayanan, Suasana Cafe, Kepuasan Konsumen

\section{Pendahuluan}

Pada era kompetisi bisnis yang ketat seperti sekarang, jumlah merek dan produk baik barang maupun jasa yang bersaing di pasar menjadi sangat banyak sehingga konsumen memiliki ragam pilihan dan alternatif, khususnya di bidang jasa. Sebagian besar produk jasa yang abstrak dan tidak terwujud, 
mempunyai aspek yang berada di sekitar inti perusahaan menjadi pertimbangan bagi konsumen. Salah satu aspek tersebut adalah lingkungan tempat penyampaian jasa tersebut berada (servicescape). Ketatnya persaingan dan semakin meningkatnya ekspetasi konsumen terhadap sebuah produk, terkhusus produk jasa membuat perusahaan harus memiliki cara untuk meningkatkan proposisi nilai. Salah satu produk jasa yang merasakan ketatnya persaingan perusahaan jasa saat ini adalah bisnis Cafe. Eksistensi Cafe di Palangka Raya, telah menjadi pemandangan sehari-hari khususnya di kalangan mahasiswa. Beragam nama cafe dengan berbagai macam jenis makanan, minuman yang ditawarkan dari yang tradisional hingga modern, dan hal inilah yang terjadi di era baru generasi cafe, tidak bisa dipungkiri kehidupan mahasiswa di Palangka Raya tidak lepas dari kehidupan malamnya baik dari nongkrong di cafe, hang out, dan lain sebagainya yang semua membentuk menjadi satu komunitas dan menjadi perwujudan budaya modernisasi. Oleh karena itu, penulis tertarik untuk melakukan penelitian di cafe Palangka Raya yang cukup terkenal dikalangan mahasiswa dan pelajar yaitu About Something Coffee, karena di About Something Coffee cukup banyak mampu menarik perhatian para konsumen untuk datang ke cafenya mengingat sekarang di Palangka Raya sudah banyak sekali café sejenis sehingga peneliti tertarik untuk mengetahui apasaja dimensi yang mempengaruhi kepuasan konsumen. About Something Coffee dikenal sebagai tempat nongkrong dan ngopi, dengan tempat dan suasana yang nyaman, serta harga yang terjangkau, membuat cafe ini sangat ramai dikunjungi. untuk memperluas segmen pasar, pihak cafe tidak hanya menyediakan minuman kopi saja namun mereka juga menyediakan variasi yang lebih banyak. Variasi tersebut adalah kopi-kopi blend dingin dan jenisjenis makanan, minuman yang biasa disajikan di cafe.

Suasana cafe merupakan salah satu faktor penunjang bisnis cafe dimana atmosphere yang tercipta dapat membuat konsumen merasakan sesuatu yang berbeda di setiap cafe yang mereka datangi. Suasana cafe yang tercipta dengan desain interior maupun eksterior, musik, penerangan dan segala sesuatu yang akhirnya membentuk perasaan nyaman atau kecewa yang dapat dirasakan oleh konsumen. Pemahaman tentang perilaku mereka sangat penting karena dapat dijadikan modal penting bagi perusahaan untuk mencapai tujuannya termasuk salah satunya adalah mencapai kepuasan mereka (konsumen). Menurut Zeithaml dan Bitner (2003:86), kepuasan konsumen merupakan "custumer's evaluation of a product or service in terms of wheter that product or service has met their needs and expectation." Konsumen yang merasa puas pada produk/jasa yang dibeli dan digunakannya akan kembali menggunakan jasa/produk yang ditawarkan. Hal ini akan membangun kesetiaan konsumen. Berdasarkan latar belakang yang sudah diuraikan, maka penulis mengambil penelitian yang berjudul "Pengaruh Kualitas Pelayanan, Harga, dan Suasana Cafe terhadap Kepuasan Konsumen Pada Cafe About Something Palangka Raya".

\section{Metode}

Penelitian ini menggunakan metode penelitian kuantitatif karena pada penulisan menggunakan statistik sederhana.Pendekatan kuantitatif merupakan penelitian yang berlandasakan pada filsafat positivism untuk meneliti populasi atau sampel tertentu dan penganmilan sampel secara random dengan pengumpulan data menggunakan instrument, analisis data bersifat statistik. Survei penelitian ini dilaksanakan melalui teknik pengumpulan informasi yang dilakukan dengan menyusun daftar pertanyaan (kuesioner) untuk diajukan kepada responden. Adapun populasi dalam penelitian ini adalah konsumen dengan jumlah tidak diketahui (infinity), di About Something Coffee jl Cut Nyak Dien Palangka Raya. Sampel merupakan bagian dari populasi yang diambil untuk mewakili keseluruhan populasi. Maka sampel dalam penelitian ini adalah 96,4 responden yang dibulatkan menjadi 96 orang responden.

Teknik analisi data yang dipergunakan dalam kegiatan penelitian ini adalah menggunakan rumus persentase". Berdasarkan pernyataan diatas maka dapat ditarik kesimpulan dari persentase terbanyak yang akan dijadikan sebagai acuan. Data yang telah disusun dikelompokan, disajikan dan dianalisa dalam bentuk distribusi sederhana. Analisis dilakukan untuk setiap item dengan cara menghitung persentase distribusi frekuensi alternative jawaban responden untuk menghitungnya dicari 
berdasarkan jumlah frekuensi yang dibagi dengan responden (n) dan di kali $100 \%$ dengan rumus sebagai berikut: $p=\frac{F}{N} \times 100 \%$.

\section{Hasil dan Pembahasan}

Hasil ini menunjukan bahwa penelitian ini relevan dengan teori bahwa kepuasan pelanggan merupakan suatu pemenuhan harapan, pelanggan dapat dikatakan puas dengan produk maupun pelayanan apabila harapan pelanggan akan produk/pelayanan yang diberikan tersebut telah sesuai bahkan melebuhi harapah mereka.

Berdasarkan hasil data yang sudah diolah tingkat kepuasan konsumen pada dimensi harga yang paling tinggi adalah pada pernyataan harga makanan dan minuman di About Something Coffee stabil $50 \%$ pada kolom puas. Harga makanan dan minuman yang disediakan di About Something Coffee sudah sangat stabil disesuaikan dengan kualitas rasa yang diberikan serta sesuai dengan target utama dari café ini yaitu mahasiswa/pelajar, jadi harganya berada di angka ya ng stabil. Harga yang disediakan di About Something cukup terjangkau sesuai dengan segmen pasar yang dipilih, harga juga disesuaikan dengan kualitas produk. Kesesuaian harga dengan manfaat produksi hal ini sudah termasuk dalam indikator yang mencirikan harga. Sedangkan tingkat kepuasan konsumen pada dimensi harga yang paling rendah adalah pada pernyataan harga makanan dan minuman di About Something Coffee menjadi alasan untuk berkunjung kembali $5 \%$ pada kolom kurang puas. Sedikit dari pelanggan About Something yang memilih kembali untuk membeli makanan atau minuman karena harganya, karena sesuai dengan hasil dari penelitian ini diketahui bahwa faktor tertinggi pelanggan merasa puas ada dikarenakan adanya rasa puas pada dimensi suasana, jadi harga merupakan bagian kecil bagi para pelanggan untuk kembali berkunjung di About Something Coffee.

Berdasarkan hasil data yang sudah diolah tingkat kepuasan konsumen pada dimensi kualitas pelayanan yang paling tinggi adalah pada pernyataan pelayanan yang ditawar About So mething Coffee sudah terpercaya $59 \%$ pada kolom sangat puas. Dari sini dapat kita ketahui bahwa pelayanan yang diberikan oleh About something coffe sudah mampu memberikan rasa percaya dari konsumennya, serta pelayan di About something coffee sudah mempunya dimensi kualitas pelayanan seperti, fasilitas fisik, kredibilitas, kompeten, handal, sopan, dapat memahami pelanggan, dapat berkomunikasi dengan baik, mampu memahami pelanggan serta memberikan rasa aman bagi para pelanggannya. Sedangkan tingkat kepuasan konsumen pada dimensi kualitas pelayanan yang paling rendah adalah pada pernyataan fasilitas Gedung yang ada di About Something Coffee lengkap (toilet, kipas angin, meja/kursi) 3\% pada kolom tidak puas. Dibalik semua dimensi kualitas pelayanan yang dimiliki oleh pelayan About Something Coffee seperti kredibilitas, kompeten, handal, sopan, dapat memahami pelanggan, dapat berkomunikasi dengan baik, mampu memahami pelanggan serta memberikan rasa aman bagi para pelanggannya, namun ada sedikit ketidakpuasan pada fasilitas gedung yang masih belum memadai dan sesuai dengan keinginan konsumen, seperti kurangnya kursi atau meja yang ada, kurangnya kipas, dan juga tidak tersedia jaringan wifi.

Berdasarkan hasil data yang sudah diolah tingkat kepuasan konsumen pada dimensi suasana café yang paling tinggi adalah pada pernyataan tata letak atau layout yang ada di About Something Coffe sudah sesuai dan rapi $70 \%$ pada kolom puas Faktor-faktor yang dapat mempengaruhi dalam menciptakan Suasana ada beberapa faktor yang berpengaruh dalam menciptakan suasana menurut Lamb, Hair dan McDaniel (2001:108) dan salah satunya mampu diterapkan oleh About something Coffee adalah Jenis barang dan tata letak suatu barang yang dipajang, $70 \%$ pelanggan merasa puas dengan penataan yang ada di About Something Coffee yang dapat membuat para pelanggan menjadi lebih nyaman untuk bersantai dan mengobrol. Sedangkan tingkat kepuasan konsumen pada dimensi suasana yang paling rendah adalah pada pernyataan sirkulasi udara dan suhu di About Something Coffee terasa segar baik dalam ruangan yang terbuka dan tertutup $2 \%$ pada kolom tidak puas. Pada About Something Coffee terbagi menjadi 2 yaitu bagian dalam, jadi jika saat siang hari bagian luar café sangat terasa panas karena kurangnya tanaman seperti pohon yang mampu mengurangi terik matahari, dan untuk diketahui bersama bagian depan café itu terdiri dari dinding yang dibuat darikaca 
dan itu menyerap banyak panas pada siang hari yang akan mengakibatkan bagian dalam café terasa sangat panas hingga pada malam hari.

Berdasarkan hasil data yang sudah diolah tingkat kepuasan konsumen pada dimensi kepuasan konsumen yang paling tinggi adalah pada pernyataan anda merasa nyaman dan santai ketika berkunjung di About Something Coffee $56 \%$ pada kolom puas. Dengan semua yang sudah diberikan oleh About Something Coffee pelanggannya sudah merasa nyaman dengan suasana, harga, pelayanan seperti sudah dijelaskan diatas, dengan terciptanya rasa nyaman yang diberikan About Something Coffe membuat pelanggang akan datang lagi untuk berkunjung. Sedangkan tingkat kepuasan konsumen pada dimensi kepuasaan konsumen yang paling rendah adalah pada pernyataan anda puas dengan fasilitas yang disediakan oleh About Something coffe $7 \%$ pada kolom cukup puas. Seperti yang sudah dijelaskan pada bagian kualitas pelanggan memang diketahui bahwa fasilitas yang ada di About something coffe masih belum memadai banyak hal yang harus diperhatikan untuk dapat menambah tingkat kepuasan dari pelanggan sehingga dapat menarik minat pelanggan untuk datang lagi.

Berdasarkan hasil data yang sudah diolah tingkat kepuasan konsumen dari ketiga dimensi yang ada dapat diketahui yang paling tinggi ada pada dimensi suasana $51 \%$ pada kolom "Puas". Nilai yang diperoleh menunjukan bahwa konsumen merasa puas dengan suasana yang ada di About Something Coffe, seperti interior yang sudah cukup menarik, papan nama sangat jelas dan mudah dikenali, tata letak sudah sesuai dan rapi, pencahayaan yang memadai, suara musik yang membuat nyaman dan tersedia ruangan yang tebuka dan tertutup. Dengan demikian dapat disimpulkan bahwa dimensi suasana berpengaruh positif dan signifikan terhadap variabel kepuasan konsumen pada About Something Coffee Palangka Raya. Sedangkan yang paling terendah dari ketiga dimensi adalah pada dimensi kualitas pelayanan 3\% pada pernyataan fasilitas Gedung yang ada di About Something Coffee lengkap (toilet, kipas angina, meja/kursi). About Something Coffee harus berusaha lagi untuk meningkatkan fasilitas yang ada di About Something Coffee untuk upaya peningkatan kepuasan pelanggannya.

\section{Kesimpulan}

Tingkat kepuasan konsumen di About Something Coffee Berdasarkan hasil analisis data yang sudah diolah maka dapat diketahui bahwa kepuasan konsumen About Something Coffee adalah:

1. Dimensi Kualitas Pelayanan diketahui persentase tertinggi pada kolom puas $46 \%$, dan persentase terendah pada kolom kurang puas, $0,1 \%$ tidak puas. Pada penelitian ini dapat diketahui bahwa konsumen lebih tertarik item pernyataan Karyawan di About Something Coffee melayani dengan jujur.

2. Dimensi Harga diketahui persentase tertinggi pada kolom puas $43 \%$, dan persentase terendah kurang puas $5 \%$. Pada penelitian ini dapat diketahui bahwa konsumen lebih tertarik item pernyataan Harga makanan dan minuman di About Something Coffee stabil.

3. Dimensi Suasana diketahui persentase tertinggi pada kolom puas $51 \%$ dan persentase terendah pada kolom kurang puas 3\%. Pada penelitian ini dapat diketahui bahwa konsumen lebih tertarik item pernyataan Tata letak atau layout yang ada di About Something sudah sesuai dan rapi

4. Dimensi Kepuasan Konsumen diketahui persentase tertinggi pada kolom puas $49 \%$, dan persentase terendah pada kolom cukup puas $16 \%$. Pada penelitian ini dapat diketahui bahwa konsumen lebih tertarik item pernyataan Anda merasa nyaman dan santai ketika berkunjung di About Something.

\section{Daftar Pustaka}

Assauri, Sofjan, 2000. Manajemen Pemasara: Dasar, Konsep dan Strategi, PT Raja Grafindo Persada, Jakarta.

Bayu Swastha, 2001. Manajemen Pemasaran Modern: Yogyakarta:BPFE

Budiyono. 2009. Statistika untuk Penelitian. Surakarta: UNS Press

Brostin Debora Sinaga. 2019. Analisis Persentase Distribusi Frekuensi Dimensi Kepuasan pengguna Sepeda Motor Honda Do Dealer Armada Tunas Jaya Abadi Palangka Raya. 
Fardiani, Aprillia Nia. 2013. Analisis Pengaruh Kualitas Pelayanan, Harga, Dan Promosi Terhadap Kepuasan Pelanggan (Studi pada konsumen Dyriana Bakery \& Café Pandanaran Wilayah Semarang). Skripsi yang dipublikasikan. Semarang: Fakultas Ekonomika dan Bisnis. Universitas Diponegoro. Diakses 28 Januari 2020.

Furchan, A, 2004. Pengantar Penelitian dalam Pendidikan. Yogyakarta:BPFE.

Gerson, R. 2004. Mengukur Kepuasan Pelanggan. Jakarta:PPM

Harianto, David dan Hartono Subagiao. 2013. "Analisa Pengaruh Kualitas Layanan, Brand Image, dan Atmosfer Terhadap Loyalitas Konsumen Dengan Kepuasan Konsumen Sebagai Variabel Intervening Konsumen Kedai Deja- Vu Surabaya," e-Jourmal Universitas Kristen Petra Jurusan Manajemen Pemasaran, Vol.1. Diakses 28 Januari 2020

Kotler, Philip. 2002. Manajemen Pemasaran: Analisa perencanaan, Implementasi dan Kontrol. Jakarta: Selemba Empat.

Kotler, 1993, Manajemen Pemasaran: Analisis, Perencanaan, Implementasi, dan Pengendalian, LPFE-UI, Jakarta

Kotler, Phillip dan Kevin Lane Keller. 2009. Manajemen Pemasaran, Edisi 13 Jilid 2, Jakarta: Erlangga Lupiyoadi, Rambat. 2013. Manajemen Pemasaran Jasa. Jakarta: Selemba Empat.

Martono, Nanang. 2010. Metode Penelitian Kuantitatif. Jakarta: PT Raya Grafindo Persada.

Martono, Nanang. 2011. Metode Penelitian Kuantitatif. Jakarta: PT Raya Grafindo Persada.

Ngadiman. 2015. "Pengertian Harapan Pelanggan". http://ssbelajar.blogspot.co.id/2014/05/pengertian-harapan pelanggan.html

Nugraha, Ruli. 2010. "Faktor -faktor yang mempengaruhi tingkat harga". http://marketingyuuk.blogspot.co.id/2010/05/faktor-faktor-yang- mempengaruhitingkat.html.

Public Service Communication.2014."Kualitas Pelayanan Menurut Zeithaml".http://dreaspsckamis.blogspot.co.id/2014/16/kualita-pelayanan-menurutzeithaml/.html.

Supranto, j, 2001.Pengukur Tingkat Kepuasan Pelanggan. Jakarta: PT Rineka, Cipta, Cet III. Sugiyono, 2005. Metodologi Penelitian. Bandung: Alfabeta.

Sugiyono, 2009. Penelitian Pendidikan Pendekatan Kuantitatif, Kualitatif, dan R\&D (Bandung alfabeta, Bandung)

Sumadi Suryabrata, 2008. Metodologi Penelitian, Jakarta: Raja Grafindo.

Susanti, R., Uda, T., \& Alexandro, R. 2019. Kualitas Pelayanan Jasa Pada Usaha Laundry Ririn Di Jalan G. Obos XII Kota Palangka Raya. Jurnal Pendidikan IImu Pengetahuan Sosial (JPIPS), 11(02), 244251.

Sartika, Yunisa., Tonich Uda, Rinto Alexandro. 2019. Pengaruh Kualitas Jasa Pelayanan Terhadap Kepuasan Konsumen Pada Toko Cahaya Di Kecamatan Laung Tuhup Kabupaten Murung Raya. Jurnal Pendidikan IImu Pengetahuan Sosial (JPIPS), 11(2): 296-301. https://ejournal.upr.ac.id/index.php/JP-IPS/article/view/514

Tjiptono Fandy, 2007. Pemasaran Jasa, Yogyakarta: Andi Yogyakarta.

Utami, Novia. 2018. "4 Metode Mengukur Kepuasan Pelanggan dengan Tepat https://www.jurnal.id/blog/2018-ketahui-4-metode-mengukur-kepuasan-pelanggan/

Vivianli Liu. 2016. Analisis Pengaruh Kualitas Pelayanan, Harga, Dan Suasana Cafe Terhadap Kepuasan Konsumen Studi Kasus pada Konsumen di Goeboex Coffee Yogyakarta J1. Perumnas, Caturtunggal, Depok, Sleman, Yogyakarta 